John Massie ＯRCID iD: 0000-0003-1008-0967

\title{
Viral Induced Hypersecretion of Mucous (VIper)
}

We wish to report a clinically distinct phenotype of viral induced lower respiratory disease, predominantly presenting in pre-school children. The clinical pattern is viral prodrome, rapid progression to tachypnoea, moist cough and hypoxia, but without wheeze or prolonged expiration. The children have a normal respiratory cycle distinguishing them from viral-induced wheeze. The degree of hypoxia is out of proportion to the respiratory effort, suggesting ventilation/perfusion (V/Q) mismatch. ${ }^{1}$ The hypoxia may improve after coughing. The radiographic findings may include patchy infiltrates with atelectasis, but hyperinflation is notably absent. The acute radiographic findings may induce antibiotic prescription, but rarely are the children toxic to suggest a secondary bacterial infection.

The children have a poor response to bronchodilators and corticosteroid therapy. Some children may have frequent episodes, but they rarely persist after school age. The hallmark of this acute phenotype is mucous hypersecretion causing V/Q mismatching in response to viral infection. The other hallmark is that once recovered, the children are completely healthy, with no residual airway disease suggesting there is no long-term airway inflammation or hypertrophy of airway mucous glands.

It is important to recognise this as a distinct lower respiratory phenotype since inappropriate salbutamol use may exacerbate the V/Q mismatching, worsening hypoxia. Salbutamol is not exclusively a $\beta_{2}$ receptor agonist, but has some $\beta_{1}$ agonist effect and may impair pulmonary perfusion. ${ }^{2}$ Furthermore, the aetiology of the phenotype is airway obstruction by mucous, not bronchial wall smooth muscle contraction. Antimuscarinics and corticosteroids do not reduce the mucous secretion. Treatment is supportive; oxygen, high-flow nasal prong air-flow, continuous positive airway support or ventilation.

Mucous hypersecretion involves multiple genetic and immumomodulatory factors in airway Goblet and mucous glands, with distinct stages of production, secretion and mucin cross linking. ${ }^{3}$ There is no pattern in these patients to give a clue as to where the pathogenesis lies. No particular virus or mycoplasma infection is linked.

This condition is often labelled "hypersecretory asthma". This is a problematic label as it places the condition under the asthma phenotype and drives inappropriate, and possibly, harmful therapy. This is a distinct viral-induced lower respiratory disease phenotype, some children responding to the viral infection with hypersecretion of mucous. We offer the label of "VIper" (Viral Induced

This is the author manuscript accepted for publication and undergone full peer review but has not been through the copyediting, typesetting, pagination and proofreading process, which may lead to differences between this version and the Version of Record. Please cite this article as doi: 10.1002/ppul.24316.

This article is protected by copyright. All rights reserved. 
hypersecretion of mucous) to help clinicians avoid inappropriate therapy that can ensue from the wrong diagnosis.

\section{References}

1. Iven H Young PTB. Gas Exchange in Disease: Asthma, Chronic Obstructive Pulmonary Disease, Cystic Fibrosis, and Interstitial Lung Disease. Comprehensive Phsyiology 2011;1:663-97.

2. Goodman and Gilman's The Pharmacological Basis of Therapeutics 12th edition. New York: McGraw Hill Medical 2011.

3. Rogers DF. Airway mucus hypersecretion in asthma: an undervalued pathology? Current Opinion in Pharmacology 2004;4:241-50. 


\section{University Library}

\section{- M M I N E R VA A gateway to Melbourne's research publications}

Minerva Access is the Institutional Repository of The University of Melbourne

Author/s:

Massie, J;Robertson, CF

Title:

Viral induced hypersecretion of mucous (VIper)

Date:

2019-06-01

Citation:

Massie, J. \& Robertson, C. F. (2019). Viral induced hypersecretion of mucous (VIper).

PEDIATRIC PULMONOLOGY, 54 (6), pp.683-683. https://doi.org/10.1002/ppul.24316.

Persistent Link:

http://hdl.handle.net/11343/285687 